\title{
Organic waste biorefineries: looking towards implementation*
}

\section{Luca Alibardi $^{\text {*** }}$, Thomas F. Astrup ${ }^{2}$, Fabiano Asunis ${ }^{3}$, William P. Clarke ${ }^{4}$, Giorgia De Gioannis ${ }^{3,5}$,} Paolo Dessi ${ }^{6}$, Piet N.L. Lens ${ }^{6}$, Maria Cristina Lavagnolo ${ }^{7}$, Lidia Lombardi ${ }^{8}$, Aldo Muntoni ${ }^{3,5}$, Alberto Pivato $^{7}$, Alessandra Polettini ${ }^{9}$, Raffaella Pomi ${ }^{9}$, Andreina Rossi ${ }^{9}$, Alessandro Spagni ${ }^{10}$, Daniela Spiga $^{3}$

${ }^{1}$ Cranfield Water Science Institute, School of Water, Environment and Energy, Cranfield University, Bedford, MK43 OAL, UK

${ }^{2}$ Department of Environmental Engineering, Technical University of Denmark, 2800 Kgs. Lyngby, Denmark

${ }^{3}$ Department of Civil and Environmental Engineering and Architecture, University of Cagliari, Piazza d'Armi, 09123 Cagliari, Italy

${ }^{4}$ Schools of Civil and Chemical Engineering, The University of Queensland, Brisbane 4072, Australia

${ }^{5}$ IGAG - CNR, Environmental Geology and Geoengineering Institute of the National Research Council, Piazza d'Armi, 09123 Cagliari, Italy

${ }^{6}$ National University of Ireland Galway, University Rd, H91 TK33 Galway, Ireland

${ }^{7}$ Department of Civil, Environmental and Architectural Engineering (ICEA). University of Padova, Via Marzolo, 9 - 35131 Padova, Italy

${ }^{8}$ Niccolò Cusano University, via don Carlo Gnocchi 3, Rome, 00166, Italy

${ }^{9}$ Department of Civil and Environmental Engineering, University of Rome "La Sapienza”, Via Eudossiana 18, 00184 Rome, Italy

${ }^{10}$ Laboratory of Technologies for Waste, Wastewater and Raw Materials Management, Italian National Agency for New Technologies, Energy and Sustainable Economic Development (ENEA), via M.M. Sole 4, Bologna, 40129, Italy

* This position paper presents the view of the authors, as members of the IWWG Task Group on Waste Biorefinery, about critical aspects of the concept of organic waste biorefinery, it discusses the role of this concept on modern waste management strategies and indicates possible ways to achieve implementation.

** Corresponding author for the submission: luca.alibardi@gmail.com - I.alibardi@cranfield.ac.uk

\begin{abstract}
The concept of biorefinery expands the possibilities to extract value from organic matter either in form of bespoke crops or organic waste. The viability of biorefinery schemes depends on the recovery of higher-value chemicals with potential for a wide distribution and an untapped marketability. The feasibility of biorefining organic waste is enhanced by the fact that the biorefinery will typically receive a waste management fee for accepting organic waste.
\end{abstract}


The development and implementation of waste biorefinery concepts can open up a wide array of possibilities to shift waste management towards higher sustainability. However, barriers encompassing environmental, technical, economic, logistic, social and legislative aspects need to be overcome. For instance, waste biorefineries are likely to be complex systems due to the variability, heterogeneity and low purity of waste materials as opposed to dedicated biomasses. This article discusses the drivers that can make the biorefinery concept applicable to waste management and the possibilities for its development to full scale. Technological, strategic and market constraints affect the successful implementations of these systems. Fluctuations in waste characteristics, the level of contamination in the organic waste fraction, the proximity of the organic waste resource, the markets for the biorefinery products, the potential for integration with other industrial processes and disposal of final residues are all critical aspects requiring detailed analysis. Furthermore, interventions from policy makers are necessary to foster sustainable bio-based solutions for waste management.

Keywords: organic waste; biorefinery; pre-treatment; biological processes; thermal processes; implementation 


\section{Introduction}

Organic waste treatment has traditionally been based on layouts involving a single bioprocess such as composting or anaerobic digestion, and in some cases a combination of the two (Ma and Liu, 2019; Cossu, 2009). Composting is a simple process that can be implemented for solid organic waste with relatively small capital investments. The composting process, however, involves an energy-intensive treatment due to the need for forced aeration; at the same time, the marketability of the final product may be limited due to very low market prices or lack of acceptance from final users (e.g. farmers) if compost quality is compromised by the presence of contaminants (e.g. high metals concentration) or undesired components (e.g. plastics) (Cattle et al., 2020; Asquer et al., 2019). Anaerobic digestion has been increasingly practised over the last two decades for the treatment of both solid and liquid municipal and industrial organic residues, with economic incentives coming from government policies being key drivers for process implementation. Such incentives stimulate the production of electric energy, thermal energy or biomethane from biogas as a renewable resource to be exploited beyond the plant boundaries (Kapoor et al. 2019; Kougias and Angelidaki, 2018; De Gioannis et al., 2017). The total installed electric capacity of anaerobic digesters in Europe has almost tripled during the last ten years (from 4158 in 2010 to $10532 \mathrm{MW}$ in 2017; EBA, 2018), contributing to achieve renewable targets for energy production in many countries (e.g. the energy roadmap defined by the EU; European Commission, 2011).

In a world with finite resources, waste or residues, including organic waste, must be considered as sources of secondary raw materials. Currently, recovery of the organic waste "value" is obtained in the form of only a few products, e.g. biogas, compost, and nutrients in the liquid phase of the digestate. These have a relatively low economic value, often supported by incentives for the production of renewable energy granted by environmental and energy policies adopted in some countries (Clarke, 2018).

A shift to renewable resources (e.g. green hydrogen, biofuels, bioplastics) (Papież et al., 2018, Carley and Browne, 2013; Lu et al., 2013), driven by businesses and the general public looking to 
implement circular economy principles, (Sarc et al., 2019; Walmsley et al., 2019; Vrancken et al., 2017) has changed the perception of organic waste. Organic waste materials are now seen as readily available and widely distributed and flexible renewable resource (Ma et al., 2018; Girotto et al., 2015; Diacono and Montemurro, 2010). This has moved the frontiers of organic waste management towards more ambitious and articulated targets that may be fulfilled by the implementation of the waste biorefinery concept.

A number of definitions exists for biorefinery (Schieb et al., 2015) but in essence all refer to a series of processes converting biomass into chemicals, material and fuels (Schieb et al., 2015; Dubois, 2012; Cherubini et al., 2009). An organic waste biorefinery can therefore be an evolution of the biorefinery notion to include waste as an alternative to dedicated biomass or to introduce a management practice enhancing the recovery of value from organic waste. The concept has raised great interest in the last years as technologies to recover value from waste feedstocks have been improved ensuring its environmental and economic sustainability (Cristóbal et al., 2018; Go et al., 2019). The range of products from a biorefinery receiving organic waste may be limited by the variability of the waste stream, but organic waste can also be homogeneous waste such as agroindustrial by-products or surplus materials which can be as defined as dedicated crops (Caldeira et al., 2020). In this paper, the terms organic waste or waste feedstock were used in the broadest sense to include any biogenic waste, effluent, by-product and production surplus (Fava et al., 2015; Coma et al., 2017).

The aim of this paper is to (i) provide an overview of the framework and context that organic waste biorefineries are viable, (ii) discuss critical aspects associated with future implementation, and (iii) develop recommendations for suitable configurations of organic waste biorefineries.

\section{Scope and boundary conditions for organic waste biorefineries}

The purpose of waste biorefineries is to exploit the potential of organic residues from different sources to generate a range of bioenergy, biofuel and biochemical products (Cherubini et al., 2010). 
Waste biorefineries offer platforms for integrated utilisation of a wide range of resources in organic waste. The development and implementation of the waste biorefinery concept offer a range of economic, environmental, social and political benefits:

- stimulate the engagement of local communities to promote and apply sustainable waste management strategies;

- provide a profitable alternative solution for waste management in areas with growing urbanisation; - support the implementation of circular economy principles;

- reduce the pressure on non-renewable resources;

- help diversify sources of strategic supply and decrease dependence on imported resources;

- promote distributed production systems and sustain regional and rural development;

- contribute to mitigate climate change impacts by providing useful products and off-setting the use of fossil carbon.

The general concept of a biorefinery has evolved driven by three pivotal aspects: (i) synergism with other industries; (ii) economic sustainability; (iii) environmental sustainability (Muntoni, 2019; Akhlaghi et al., 2016).

\subsection{Underlying principles of waste biorefineries}

The cascading approach involves the flexible and sequential integration of different biological, chemical and/or thermal processes aimed at producing a mix of biofuels and biomolecules to maximise production yields and incomes (Olsson et al., 2016). To this aim, both the direct and the inverse cascading approach may be implemented depending on whether bioenergy generation is downstream or upstream of biomaterials production (Poggi-Varaldo et al., 2014). The integration of processes for both cascading approaches depends on technical feasibility, economic sustainability, market conditions, environmental issues as well as local needs and constraints, and leads to a specific array of biofuels and biomaterials (Maina et al., 2017). Increasing the range of output products is expected to impact the achieved level of waste recovery preventing organic waste 
from being disposed to landfill or open dumps. The flows that are diverted from landfill would need to meet quality and technical standards specific to the biorefinery. Compared to a conventional biorefinery, a waste biorefinery would, therefore, involve an additional layer of complexity due to the variability, heterogeneity and low purity of waste materials as opposed to dedicated biomasses (Duan et al., 2020; Ubando et al., 2020; Sadhukhan and Martinez-Hernandez, 2017).

The alternative of using suitable organic waste as is without processing must always be considered, such as the application of non-putrescible crop residues on land or the use of clean food waste as animal feed (Caldeira et al., 2020; Cristobal et al., 2018; Matharu et al., 2016).

\subsection{Technical and economic sustainability}

From the technical and economic viewpoint, the main challenges involved are: (i) mitigating the impacts that the fluctuations in waste composition and characteristics can have on the array of processes adopted in a biorefinery (Matharu et al., 2016); (ii) arranging an integrated set of suitable waste materials as the feedstock to maximise the final product yield and quality (Roni et al., 2019); (iii) determining the optimal size of the system which can range from high-performance, multifeedstock installations to decentralised, more specialised systems with a reduced number of platforms (Galanopoulos et al., 2020; Roni et al., 2019); (iv) integrating the system with other industries to allow for improved circulation of materials and energy (Caldeira et al., 2020); (v) accommodating for fluctuating market demands and price volatility of products (Duan et al., 2020). Organic waste feedstocks mainly consist of agricultural and forestry waste, food processing waste and effluents, sludges, yard and organic household waste. Such diversified materials contain valuable amounts of proteins, sugars, lipids, fibres, vitamins and bioactive agents (antioxidants and antimicrobial agents, enzymes) that are worth recovering. Through specific combinations of treatments followed by proper separation and purification procedures, pigments, pharmaceuticals, flavours, organic acids, biopolymers, biofuels and soil improvers can be extracted or produced (Fava et al., 2015). 
Organic wastes represent a plurality of substrates having different characteristics and whose availability changes significantly over time. In general, post-consumer organic waste is heterogeneous but less affected by seasonal availability, while waste at the food processing stage is more homogeneous but affected by seasonality (Cristóbal et al., 2018). Differences in origin and characteristics as well as seasonality drive production strategies, design, operation, and logistic choices for a biorefinery.

The treatment train could be potentially designed to match and buffer variations. For example, biorefineries might be designed to switch between seasonal feedstocks or use mixed supplies rather than a single source. Seasonal flow can also be buffered using air-tight storage and preservation techniques such ensiling or bio-drying. The synthesis of these various approaches to manage seasonal waste would arguably require a combinatorial problem-solving approach (Pyrgakis and Kokossis, 2019).

Transportation of the waste feedstocks to the biorefinery is another main logistic issue. Whilst more attention is usually given to the choice of the value recovery processes, the feasibility analysis should include also the management of the supply-chain (Caldeira et al., 2020). Matching generation points and biorefinery location is a key factor that affects the viability of a biorefinery. In this respect Cristóbal et al. (2018) considered two diametrically opposite scenarios while performing a techno-economic and profitability analysis of four food waste biorefineries for tomato, potato, orange, and olive processing waste. Fewer large biorefinery plants co-located with the food processing plants would be effective for processing wastes from harvested goods, but would not represent the optimum transport solution for harvesting wastes and rejects, while, a strategy based on numerous smaller plants would minimise the transport costs for these in-farm wastes. The analysis stressed that few large plants would be the most profitable scenario as this allows for concentrated production, takes advantage of economies of scale, and simplifies transport logistics (Cristóbal et al., 2018). An economic analysis on a biorefinery treating citrus waste for the recovery of limonene, ethanol and biogas was performed by Lohrasbi et al. (2010). 
The ethanol production cost proved to be sensitive to the feedstock transportation costs. Increasing the transport cost from approximately 9 to $27 € /$ ton resulted in ethanol cost rising from 0.8 to 1.3 $€ / L$, a feature reported also by Satari and Karimi (2018). The economic feasibility of biorefineries for food processing waste is enhanced if the bio-refinery is co-located with the food processing plant, eliminating transport as a cost for the biorefinery (Caldeira et al., 2020).

\subsection{Environmental sustainability}

Waste management schemes are characterised by environmental impacts associated with the activities and technologies within the system, i.e. the handling and processing of waste materials. The outputs recovered or produced from waste contribute to the environmental savings by offsetting the demand for other resources. For a waste biorefinery to be environmentally sustainable, the environmental "value" of these outputs has to be higher than the "effort" invested in providing the outputs. More specifically, it is necessary to assess whether the use of organic waste as a starting material is less resource-demanding than the manufacturing of the same products from virgin materials (Cristóbal et al., 2018). The environmental performance of a biorefinery will depend on the regional settings and whether simpler alternatives such as composting or anaerobic digestion have equal or greater environmental benefit. As such, a wide range of aspects are important when assessing the environmental sustainability of a waste biorefinery, e.g. the (i) feedstock availability, composition, properties and variability which may lead to higher proportions of rejected feedstocks that require disposal, (ii) logistic issues such as transport distance and need for storage capacity, compared to that of simpler and more scalable composting or digestion plants, (iii) more elaborate process configurations, including the need for complex pre-treatments, (iv) framework conditions and integration into "surrounding" industrial and waste management sectors, (v) and management of co-products and side streams from the refinery chain. The combination of all these aspects has a strong context-specific connotation and defines the overall environmental gain achievable in comparison with the use of simpler waste management strategies. 
Collecting reliable information on the available waste feedstocks is pivotal, although data on the streams that can be intercepted are seldom available (Cristóbal et al., 2018).

Life cycle assessment (LCA) offers a systematic framework for evaluating the environmental consequences of waste management technologies and systems (e.g. ISO, 2006) with respect to a range of selected impact categories, such as climate change, resource depletion, eutrophication, and toxicity effects. Relatively few consistent LCA studies have been carried out with a focus on organic waste biorefineries, although a wider range of studies have addressed individual components such as anaerobic digestion and composting (e.g. Boldrin et al., 2011; Eriksson et al., 2005), fuel production (e.g. Venkata Mohan et al., 2016) and incineration (e.g. Astrup et al., 2015). Most of the LCA studies in literature focusing on integrated biorefinery systems have evaluated combinations of traditional waste technologies, such as material recovery facilities, anaerobic digestion, pulping and incineration, with the recovery of specific biofuels or biochemicals (e.g. Tonini et al., 2013; Sadhukhan and Martinez-Hernandez, 2017; Nizami et al., 2017; Chen et al., 2017; Moretti et al., 2017). As such, generic conclusions regarding the specific sustainability of organic waste biorefineries may be difficult to draw from existing literature due to variations in conditions and assessment approaches. However, biorefineries based on organic waste from households offer larger climate benefits compared to biorefineries that process industrial food industry (Tonini et al., 2016).

Two different LCA perspectives may be applied when evaluating the environmental sustainability of organic waste biorefineries: (i) a "waste management perspective" focusing on comparing the waste biorefinery with other (traditional) waste management options such as composting or landfilling, or (ii) an "output perspective" focusing on comparing one or more waste biorefinery products with alternative (traditional) production options. The alternative management options are important in both of these perspectives: if the waste was otherwise landfilled, the environmental benefits of waste utilisation in a biorefinery may be significantly larger than if the alternative management was anaerobic digestion or energy recovery via incineration (Astrup et al., 2015). 
This also relates to indirect effects, such as land-use-changes when crop markets are affected, e.g. organic waste fractions previously upgraded to animal feed products and now used as feedstock in biorefineries with different target outputs. In this case, the environmental impacts associated with the animal feed products need to be accounted as well. As waste biorefineries are multi-output technologies per definition, the environmental consequences associated with all outputs should be considered.

While the feedstock composition and properties can be considered fundamental for the environmental performance of waste biorefineries (Bisinella et al., 2017), also the configuration and performance of individual unit-processes are critical. Recently, Lodato et al. (2020) developed an LCA approach specifically targeted towards integrated technologies such as (waste) biorefineries, thereby demonstrating that process efficiencies and mass, energy, and substance flows within a biorefinery have profound importance for the overall environmental performance. This includes the composition of side streams, rejects and co-products from the biorefinery (e.g. digestate, fibre fractions or contaminants) and the environmental implications of their management and final disposal. An important aspect is the potential effects associated with carbon or metals sink options (Morello et al., 2018), and the risk of spreading micro-pollutants or microplastics (Butkovskyi et al., 2016).

\subsection{Market potential}

The use of organic waste as a feedstock for biorefineries can be the nexus between environmental protection, bio-economy and circular economy promoted by EU policies (European Commission, 2015). In particular, waste biorefineries could potentially exploit the untapped potential stored in approximately 130-151 million tonnes/year of biowaste estimated to be generated in the EU by 2020 (European Commission, 2011). The latest data published by Eurostat (Eurostat, 2020) indicate an actual total (municipal + industrial) production potential of about 230 million tonnes/year of organic waste for EU28 in 2016, composed of ca. $42 \%$ of animal and vegetable waste, $26 \%$ of the 
organic fraction of municipal solid waste, $20 \%$ of wood waste and $9 \%$ of non-hazardous sludge from sewage treatment plants or food processing plants.

The market targeted by waste biorefinery products has grown steadily notwithstanding the economic crisis of the last decade. The global production of organic chemicals accounts for a major share of the overall chemical industry and is estimated to amount, excluding fuels, to more than 300 Mtons/year. The associated market was worth over USD 6 billion in 2014, growing at an average rate of $8 \%$ per year from 2009 to 2014 . It is expected to reach USD 16 billion by 2025 , at a compound annual growth rate of about 7-8\% from 2019 to 2025 (Fiormarket, 2019).

The primary outputs of the traditional organic chemical industry are a relatively limited number of building blocks used to produce a plethora of end products for various sectors (e.g. food and beverages, pharmaceuticals, personal care products and cosmetics, fertilisers, pesticides, agrochemicals, water treatment chemicals, automotive components, gasoline additives and polymers).

The current global bio-based chemical and polymer production is estimated to be around 90 million tonnes. The demand for bioproducts from renewable sources is estimated to reach, depending on the market conditions, 26-113 Mtons/year in 2050, up to $38 \%$ of the total organic chemicals production. The associated market is projected to account for 7-8 billion USD, with a growth rate of $15 \%$ per year that could further benefit from the increasing demand for biopolymers (IEA Bioenergy - Task 42 Biorefinery, 2020). This indicates a market with a large potential that has not yet been tapped. Basic building blocks can indeed be obtained from organic waste, enabling the supply of raw materials from internal and diffused sources. This would de-risk the supply chain from external and potentially volatile suppliers, guarantee a secure supply at lower production and transport costs and achieve economic sustainability even for disadvantaged and isolated contexts such as, for instance, some of the main Mediterranean islands. 


\section{Implementation of waste biorefinery systems}

\subsection{From traditional biorefineries to waste biorefineries}

The technological and economic perspectives of traditional biorefineries are not entirely applicable to waste biorefineries. Waste materials fluctuate in composition (Bisinella et al., 2017; Alibardi and Cossu, 2014) and contain impurities or other undesired fractions (e.g., small plastics) that are not easily removable.

Pre-treatment of organic waste is considered a crucial step in a biorefinery scheme to cope with the complexity and heterogeneity of waste materials. The aim of pre-treatments is to remove unwanted constituents, change the physical properties of the solid matrix (e.g. its crystallinity) to speed up downstream processes (Tonini and Astrup, 2012) and make valuable components more available to subsequent treatments. Recovery of building blocks of interest for the chemical industry, which can be further transformed into compounds for downstream utilisation, often requires the isolation of homogeneous fractions and the disruption of the original chemical structure. This is particularly true for complex residual materials (e.g. lignocellulosic). Three major analysis points arise in this respect, including (i) the selectivity of the applicable pre-treatment techniques; (ii) the amount of rejected fraction generated; and (iii) the intensity (amount of chemicals and energy) of the pretreatment stages. Appropriate tools to assess the overall environmental profile and economic sustainability of the whole process should therefore be adopted to evaluate and compare different valorisation options (Albizzati et al., 2019; Astrup et al., 2018).

\subsection{Production strategies in waste biorefineries}

The simplest layouts of a waste biorefinery are those aimed at recovering low-added-value products, i.e. biofuels or energy carriers, soil improvers and fertilisers. A higher complexity is required to generate pure streams of platform chemicals for the production of biomaterials, where more specific technical standards must be met. The feasibility of a complex biorefinery with highvalue outputs is linked to the availability and type of feeding residues, the market conditions and 
demand for these products and the possibility for a waste biorefinery to be integrated within the existing industrial system (Shahzad et al., 2017). Indeed, some organic waste streams contain appreciable quantities of substances whose value may be as high as $12,000 € / \mathrm{g}$, e.g. biophenols such as hydroxytyrosol and tyrosol (Tinikul et al., 2018), or are suitable for conversion into profitable molecules and pivotal building blocks, e.g. lactic acid, acetic acid and ethanol (Moretto et al., 2019; den Boer et al., 2016). While biorefineries earn revenues from the sale of products, waste biorefineries can also earn income from gate fees. Gate fees strongly depend on the territorial context, the balance between demand and offer for waste treatment and local regulations. In an initial stage, gate fees can contribute to assuring a stable income for a waste management company to de-risk the uncertainties of a non-mature market for biofuels or bioproducts. In the long-term, the generation of high-value products might increase the profitability, allowing for reducing or even eliminating waste gate fees (Sadhukhan et al., 2018).

It is generally acknowledged that, in order to generate high-value outputs and ensure environmental sustainability (what is commonly referred to as a second-generation biorefinery), the process should be arranged to comprise two or more platforms (Budzianowski and Postawa, 2016; Naik et al., 2010). According to the definition introduced by Task 42 of the IEA (IEA Bioenergy, 2012), analogous to the petrochemical industry, platforms are intermediates linking feedstocks and final products. The combined production of multiple platforms would ensure an optimised recovery of individual precursors from the feedstock. For instance, in order to make the selling price of biofuels competitive with that of fossil fuels, it is necessary to combine biofuel production with bioproducts that have high value and a sufficiently large market. In turn, producing multiple platforms requires the integration of a range of different treatment processes, the nature of which is a function of the characteristics of both the feeding waste to be exploited and the final products. Furthermore, adequate fractionation of individual waste components may be necessary to generate an array of outputs of different characteristics. To this regard, the selectivity, accuracy and yield of separation play a key role in view of full implementation of multi-platform biorefineries. 


\subsection{Size-dependent waste biorefinery approaches}

The minimum economically viable size of complex biorefinery installations, the criteria for acceptable waste feedstocks and the viable products that can be generated from waste biorefineries is still the subject of debate. Traditional biorefineries are generally indicated as requiring large plants with a minimum size in the range of about 500,000-700,000 tons/year to ensure economic sustainability (Kuchta, 2016). Using organic waste as a feedstock for biorefineries would presumably reduce the minimum size required, because of the expected income from waste treatment fees on top of the revenues from the obtained products.

The array of options available for biorefineries may range from large, high-performance installations to decentralised, simplified-layout systems (Budzianowski and Postawa, 2016). Larger installations benefit from the economies of scale and must produce bio-commodities that feed into large markets. As a result, larger installations are expected to include more complex process layouts, integrating several platforms and processes of different nature in order to diversify, functionalise and maximise materials and energy recovery. For the same reasons, large biorefineries are also envisaged to accept a range of feedstocks, both residual and non-residual biomass, to allow for larger treatment capacity. This flexibility will accommodate the seasonal variability of organic residues and bio-product markets, although a consolidated market pattern for bioproducts, in terms of both demand and price stability, is a highly relevant prerequisite. For large-scale centralised systems, however, the need for transportation of organic residues from different sources may be a concern from both the logistical and the economic point of view. The typically low energy density and solids content of organic residues, the need to reduce the storage period to a minimum to prevent biodegradation as well as the need to develop a highly structured supply chain represent significant constraints on the siting of a biorefinery.

Small scale biorefineries involve less complex treatment layouts with lower capital and operating costs, due to a reduced number of platforms and a smaller range of end products. Decentralised 
dedicated medium- to small-scale plants will use a reduced number of feedstocks, which are expected to be available at the local scale. At the same time, decentralised installations allow the generated biofuels and biomolecules being tailored to the existing context, promoting close integration with other local industries in view of the circulation of materials and energy. The technological complexity and the industrial know-how of waste biorefineries is less developed than highly specialised chemical processing installations. It therefore appears more reliable, at least from a short-term development perspective, to conceive a waste biorefinery as a system producing intermediates, precursors or building blocks, which are then further processed beyond the boundaries of the biorefinery.

A critical risk associated with waste-derived products is the potential spreading of impurities and contaminants, either associated with the original waste or produced during the processing as a result of side reactions and/or the addition of external chemicals. This aspect should be considered in relation to all waste management and recycling systems (Astrup et al., 2018). The characteristics of final residues from complex biorefinery schemes will be different from those of traditional bioprocesses such as composting and anaerobic digestion, which needs to be considered when evaluating the feasibility of biorefinery configurations (Cattle et al., 2020; Sharma et al., 2019, Alvarenga et al., 2015). To this regard, ecotoxicological parameters can be used to determine more realistically the risk posed to ecosystems by complex and highly variable matrices. For these bioproducts, the approach proposed by Hennebert (2018), who suggested an array of ecotoxicological tests with aquatic and soil organisms, provides a good starting point.

\section{Waste biorefinery configurations}

\subsection{Multi-platform waste biorefineries}

As shown in Section 3, a unique layout of the most suitable processes to be included in an organic waste biorefinery cannot be defined. The possible options on hand are related to the quantity and characteristics of the waste, the specific local conditions and constrains, market trends and 
legislative constraints. Nonetheless, in the authors' view, anaerobic digestion, being a wellestablished biological process currently adopted for complex and heterogeneous waste at large scales, is regarded as a suitable candidate to play a central role in biorefinery schemes in the near future. Stemming from this, a potential process layout for a multi-platform, multi-product biorefinery integrating anaerobic digestion with other chemical, biochemical and thermochemical treatment units is presented in Figure 1. The proposed layout includes an initial separation of the individual components of the waste feed (carbohydrates, starch, cellulose, lignin, proteins and lipids), followed by dedicated treatments of each component to maximise the yield of biofuels and biomolecules recovery (Asunis et al., 2019; Girotto and Cossu, 2019; Alibardi and Cossu, 2016). The nature of the separation processes relies inherently on the composition and characteristics of the input waste, and may involve processes such as washing and extraction (Ao et al., 2020; Matharu et al., 2016), use of enzymes (Arbige et al., 2019; Escamilla-Alvarado et al., 2017) and solid-liquid or membrane separation processes (Abels et al., 2013; Huang et al., 2008). Waste fractionation by main chemical components enables parallel processing lines with a reliable supply with predictable composition, e.g. high carbohydrate-rich agro-food waste, protein-rich slaughterhouse waste, fat, oil and grease (FOG) waste from grease traps. 


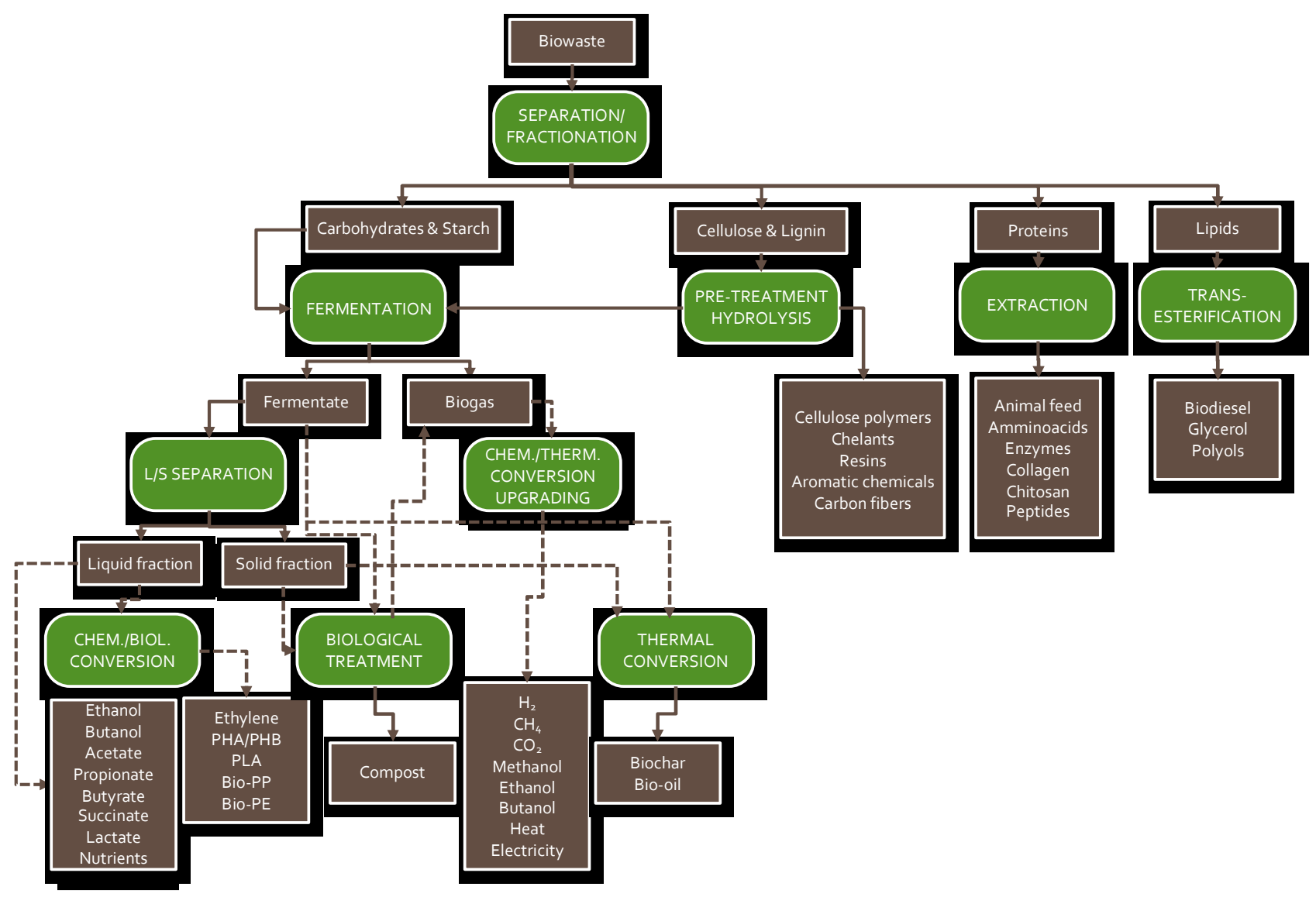

Figure 1. Layout for a multi-platform anaerobic biorefinery producing biofuels and biomolecules.

Dashed lines represent alternative options. Green blocks represent processes and brown blocks represent materials.

The list of potential products presented in Figure 1 is not exhaustive, since further processing of intermediates and precursors may lead to additional products not specifically considered in the layout provided. Furthermore, in some cases (dashed lines in Figure 1), the bioproducts included in the proposed layout are considered alternative to each other, so that the individual treatment stages can be tailored towards the desired end products depending on the specific needs.

Full implementation of a multi-platform, multi-product scheme such as the one depicted in Figure 1 implies overcoming the bottlenecks associated with conversion processes from low-purity, heterogeneous materials such as organic residues. As a result, a transition period is unavoidable prior to the full development of the whole process chain. During the transition period, in the initial implementation stages the biorefinery concept can be applied and developed by adopting simplified 
configurations based on technologies that have already been developed and demonstrated at the full scale, to reduce uncertainties on process performance. This is meant to form a processing platform basis whose complexity can be progressively increased as soon as other, more advanced options become available for implementation. Such configurations can step up in the longer term into an integrated high-performance scheme. In this regard, a number of simplified layouts representing treatment trains with a short- to medium-term application horizon can be defined, which are deemed to have the potential of being more easily implemented within the waste management sector.

\subsection{The role of dark fermentation in waste biorefineries}

Potential simplified waste biorefineries models, with dark fermentation (production of $\mathrm{H}_{2}$-based biogas and volatile fatty acids (VFAs) or alcohols) as the common initial stage followed by different treatment options depending on the target products, are outlined in Figures 2-6. Dark fermentation is the biohydrogen production option with the highest readiness for full-scale implementation (Lin et al., 2018; Chandrasekhar et al., 2015; Poggi Varaldo et al., 2014). The relatively short retention time of dark fermentation implies small reactors that can be easily retrofitted into existing single-stage digestion plants even with limited space availability.

Regardless of whether $\mathrm{H}_{2}$ is the targeted product, fermentation is central to processing carbohydrate streams. Protein and lipid-rich waste streams could also be directed through a fermenter if the competing routes and products shown in Figure 1 are not economically viable.

The layouts proposed in Figures 2-6 indicate the main (and most readily applicable) technological processes to maximise recovery of valuable products from the outflow of each stream, as well as the potential interconnections between treatment outflows. Dark fermentation plays the role of upfront treatment aimed at hydrolysing the complex starting waste materials, producing $\mathrm{H}_{2}$ and providing simpler soluble compounds for downstream processes (De Gioannis et al., 2013). More specifically, Option 1 (Figure 2) includes the following treatment stages: dark fermentation with $\mathrm{H}_{2}$ production; a second methanogenic stage for $\mathrm{CH}_{4}$ production; biogas treatment and upgrading to separate $\mathrm{H}_{2}$, 
$\mathrm{CO}_{2}$ and $\mathrm{CH}_{4}$ for subsequent uses; liquid/solid separation of the digestate; biological stabilisation of the solid fraction of digestate to produce compost (or, alternatively, thermochemical treatment to produce either biochar or pyrolytic oil); and nutrient recovery from the liquid fraction of digestate. This represents the simplest and readily applicable waste biorefinery scheme that can benefit from the strong incentives that exist in several European countries to produce biomethane (Lombardi and Francini, 2020). The gaseous products (biohydrogen and biomethane) may then be used individually or as a mixture (hythane). Biomethane can also be used as a feedstock to more advanced processes, producing single-cell proteins or other high-value bioproducts (Strong et al., 2016; Strong et al., 2015).

The $\mathrm{CO}_{2}$ in the biogas can be captured and supplied to industry or biologically converted to methane (Bajón Fernández et al., 2015) by using hydrogen. Other promising alternatives include accelerated carbonation using alkaline industrial residues (Costa et al., 2007; Sanna et al., 2014) for both carbon sequestration and waste stabilisation purposes, biological reduction of $\mathrm{CO}_{2}$ to VFAs in microbial electrochemical systems (Batlle-Vilanova et al., 2017), or cultivation of autotrophic microorganisms such as cyanobacteria or algae which could be further exploited to produce pigments, lipids, biodiesel, bio-fertilisers or bioplastics (Duppeti et al., 2017; Venkata Mohan et al., 2015).

The liquid fraction of digestate can be treated to recover nutrients. The recovered nutrients can be used as fertilisers, in novel applications as the use of ammonium for biogas upgrading (Bavarella $e t$ al., 2019) or for further $\mathrm{H}_{2}$ production via chemical cracking (Lamb et al., 2019). 


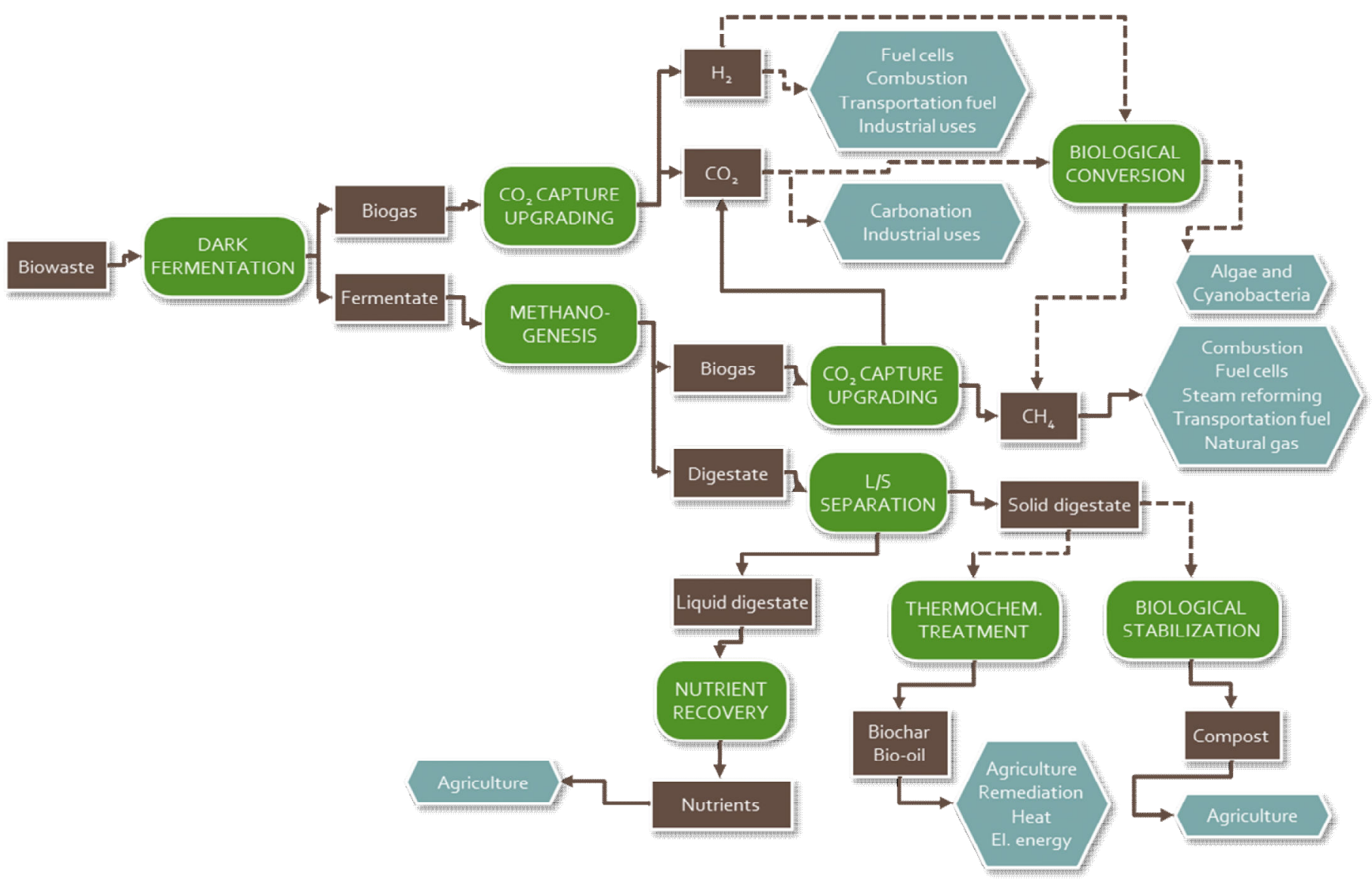

Figure 2. Simplified layout for an anaerobic waste biorefinery. Option 1: dark fermentation, methanogenesis, biogas $\left(\mathrm{H}_{2}, \mathrm{CO}_{2}, \mathrm{CH}_{4}\right)$ upgrading and digestate processing. Dashed lines represent alternative options. Green blocks represent processes, brown blocks represent materials, light blue blocks represent final uses.

In option 2 (Figure 3) the dark fermentation stage is specifically oriented to VFA (with concomitant $\mathrm{H}_{2}$ production) or bioethanol production and is therefore followed by a separation stage to fractionate and purify these compounds. Separation is the key challenge. The energy payback for alcohol is marginal if distillation is applied as a separation step. VFAs can also be directly extracted from the mixtures typically obtained via waste fermentation. Several technologies are commercially available for VFA purification from mixtures, including conventional (adsorption/desorption on ion exchange resins, liquid-liquid extraction), membrane-based (pertraction, nanofiltration) and 
electrochemical (electrodialysis) processes (Rebecchi et al., 2016; Reyhanitash et al., 2016; Outram and Zhang 2018; Xiong et al., 2015; Jones et al., 2017). However, none of them simultaneously allows high extraction efficiencies and selectivity at competitive price. Innovative separation methods for selective extraction of individual VFAs from mixtures are thus required to foster the economic sustainability of waste biorefineries. Methanogenesis can then be applied to the residual effluent resulting from the separation stage.

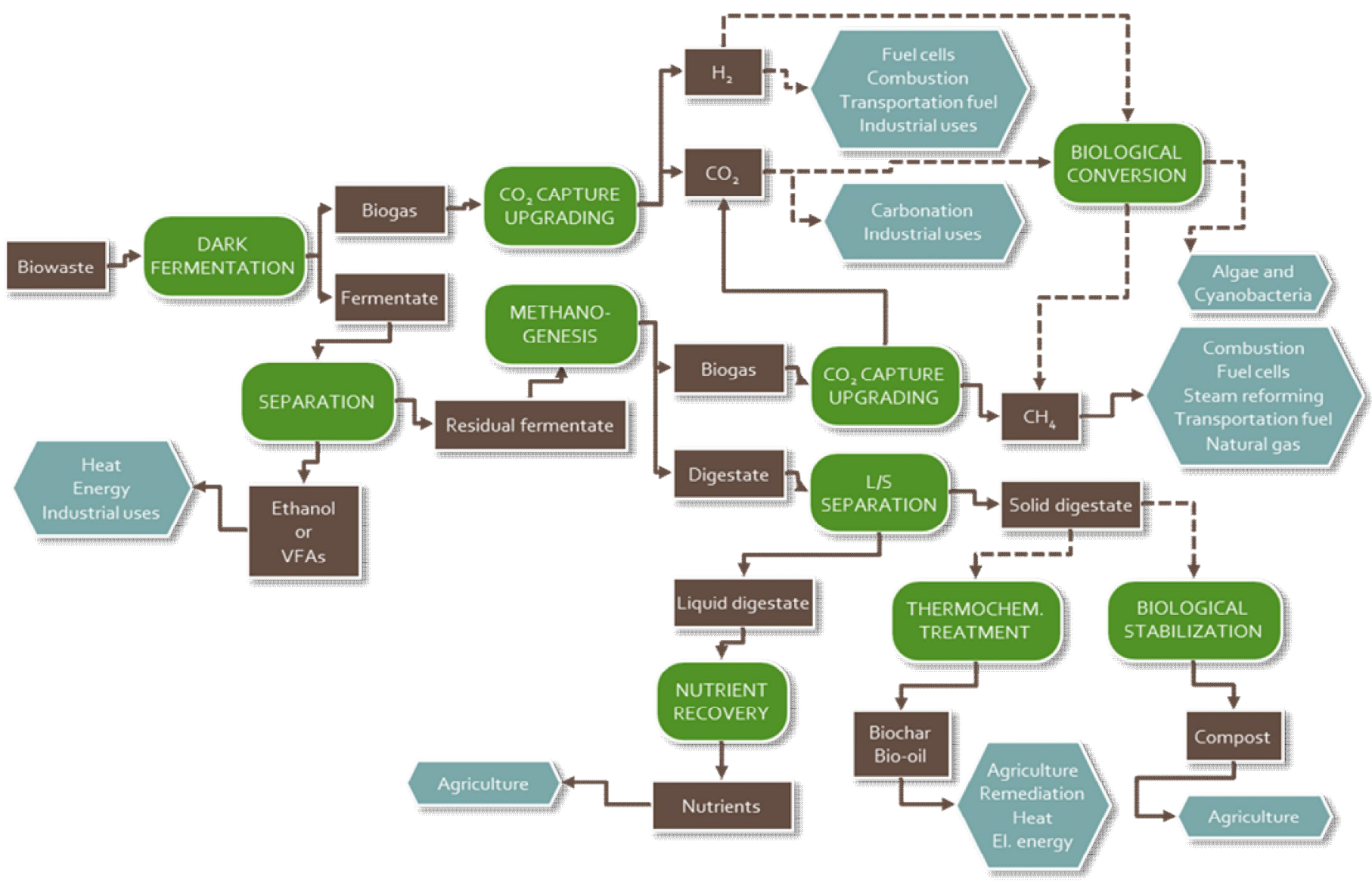

Figure 3. Simplified layout for an anaerobic waste biorefinery. Option 2: dark fermentation, ethanol/VFAs recovery, methanogenesis of the residual fermentate, biogas $\left(\mathrm{H}_{2}, \mathrm{CO}_{2}, \mathrm{CH}_{4}\right)$ upgrading and digestate processing. Dashed lines represent alternative options. Green blocks represent processes, brown blocks represent materials, light blue blocks represent final uses. 
Option 3 (Figure 4) presents an integrated process in which $\mathrm{H}_{2}$ becomes the main output of the biological treatment by coupling dark fermentation with photo-fermentation to enhance $\mathrm{H}_{2}$ yields up to $7 \mathrm{~mol} \mathrm{H}_{2} / \mathrm{mol}$ glucose (Khetkorn et al., 2017; Zhang et al., 2017). In Option 4, (Figure 5), instead, the dark fermentation effluent, rich in VFAs, is further processed biologically to induce the accumulation of biopolymers (polyhydroxyalkanoates, PHA) within the bacterial cells, which are thereafter concentrated and extracted (Valentino et al., 2017). Biopolymers can then be used in the bioplastic industry for a range of uses. Another potential alternative (Option 5; see Figure 6) involves coupling dark fermentation with an electrochemical process, that may be aimed at further $\mathrm{H}_{2}$ production (through e.g. microbial electrolysis cells), or at electricity generation (through e.g. microbial fuel cells).

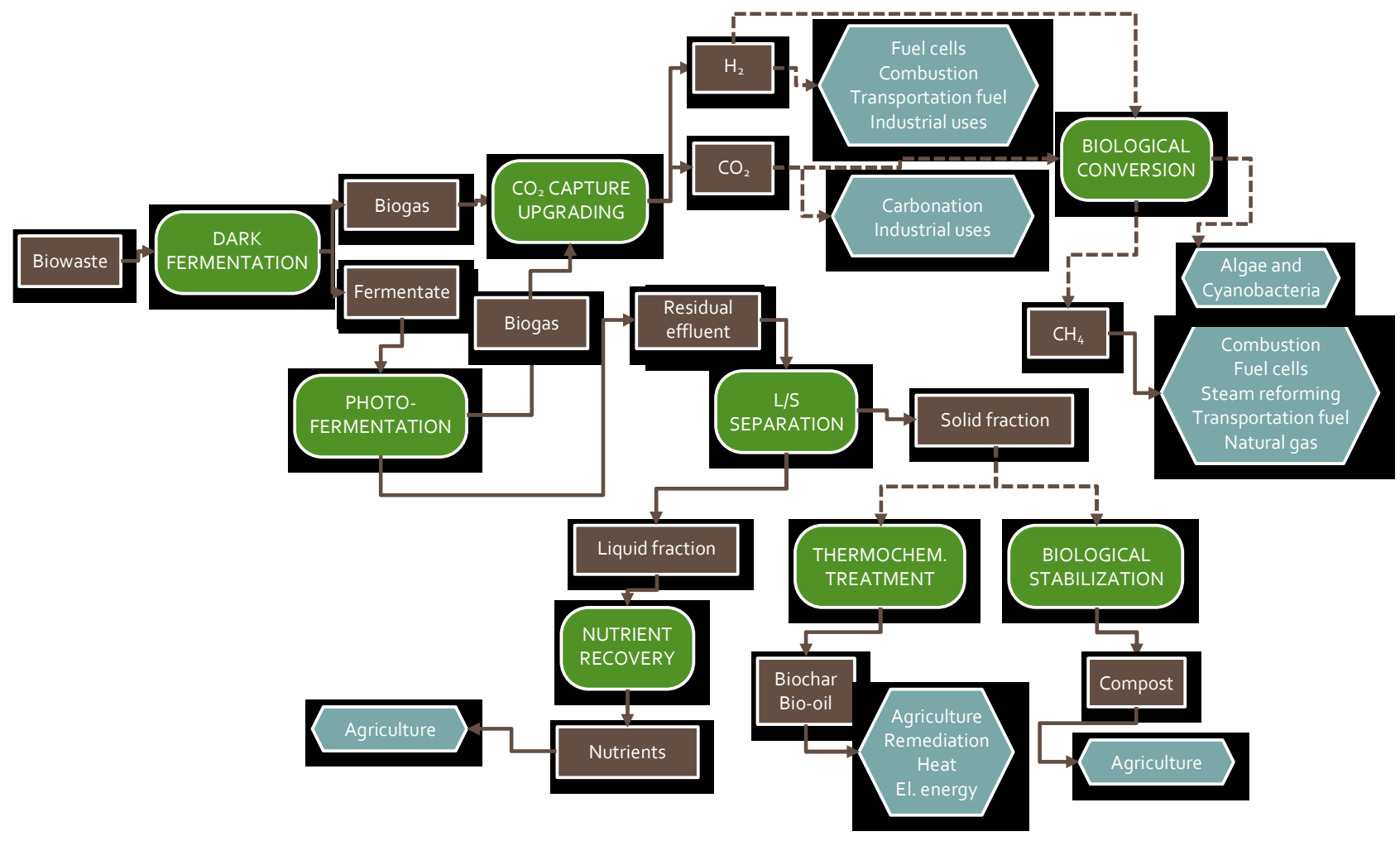

Figure 4. Simplified layout for an anaerobic waste biorefinery. Option 3: dark fermentation, photofermentation, biogas $\left(\mathrm{H}_{2}, \mathrm{CO}_{2}\right)$ upgrading and digestate processing. Dashed lines represent 
alternative options. Green blocks represent processes, brown blocks represent materials, light blue blocks represent final uses.

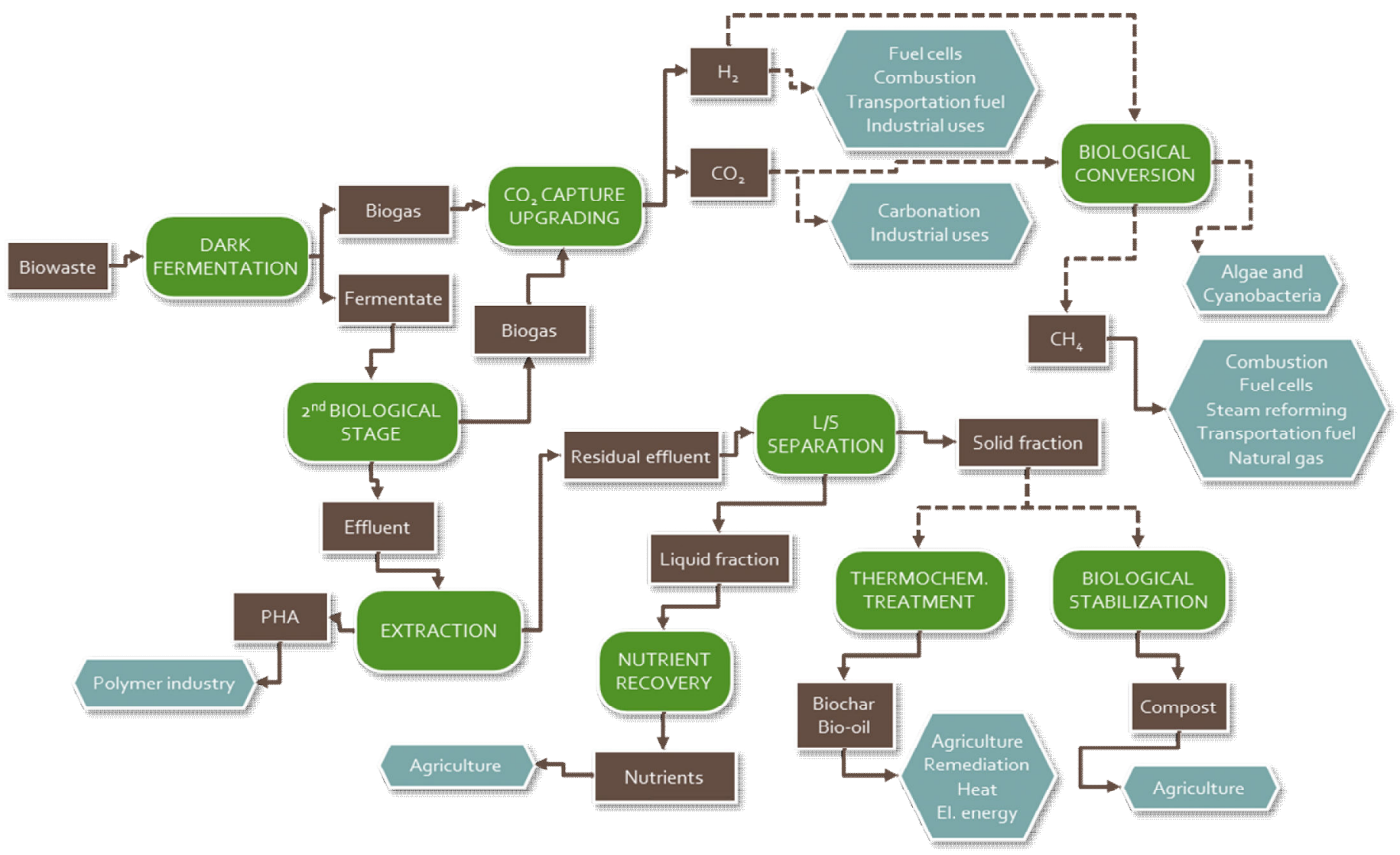

Figure 5. Simplified layout for an anaerobic waste biorefinery. Option 4: dark fermentation, biopolymer production, biogas $\left(\mathrm{H}_{2}, \mathrm{CO}_{2}\right)$ upgrading and digestate processing. Dashed lines represent alternative options. Green blocks represent processes, brown blocks represent materials, light blue blocks represent final uses. 




Figure 6. Simplified layout for an anaerobic waste biorefinery. Option 5: dark fermentation, electrochemical processing for enhanced $\mathrm{H}_{2}$ production or electricity generation, biogas $\left(\mathrm{H}_{2}, \mathrm{CO}_{2}\right)$ upgrading and digestate processing. Dashed lines represent alternative options. Green blocks represent processes, brown blocks represent materials, light blue blocks represent final uses.

\subsection{Waste biorefinery output}

A rough estimation of the potential outcomes of waste biorefineries can be derived from the observed ranges of bioproducts generation documented by literature studies. To this aim, $\mathrm{H}_{2}, \mathrm{CH}_{4}$, ethanol and PHAs were considered as examples among the several products presented in the biorefinery layouts described above thanks to a large availability of data. Since the reported yields are largely variable with respect to the specific characteristics of the waste treated, the type of conversion process applied and the operating conditions adopted, average values and deviations from literature data are shown in Figure 7. 
On the basis of the reported market prices for each product of concern (Moscoviz et al., 2018), the following ranges for the economic value of the products that can be obtained from food waste (FW) in a biorefinery application were estimated: $0.24-15.5 € / \mathrm{t} \mathrm{FW}$ (average: 4.9 ) for $\mathrm{H}_{2}, 1.9-11.6 € / \mathrm{t}$ FW (average: 7.3) for $\mathrm{CH}_{4}, 9.0-540 € / \mathrm{t} \mathrm{FW}$ (average: 229) for ethanol and 22-4500 €/t FW (average: 1510) for biopolymers. The revenues achievable from biowaste in a biorefinery would require deducting the capital and operating costs of the plant. Nonetheless, given the amount of food waste generated (in Europe, 46.5 and $41.1 \mathrm{Mt} / \mathrm{y}$ from municipal and industrial sources, respectively), as well as the incentives for the production of green chemicals and energy, considerable financial benefits are expected from the wide implementation of organic waste biorefineries.
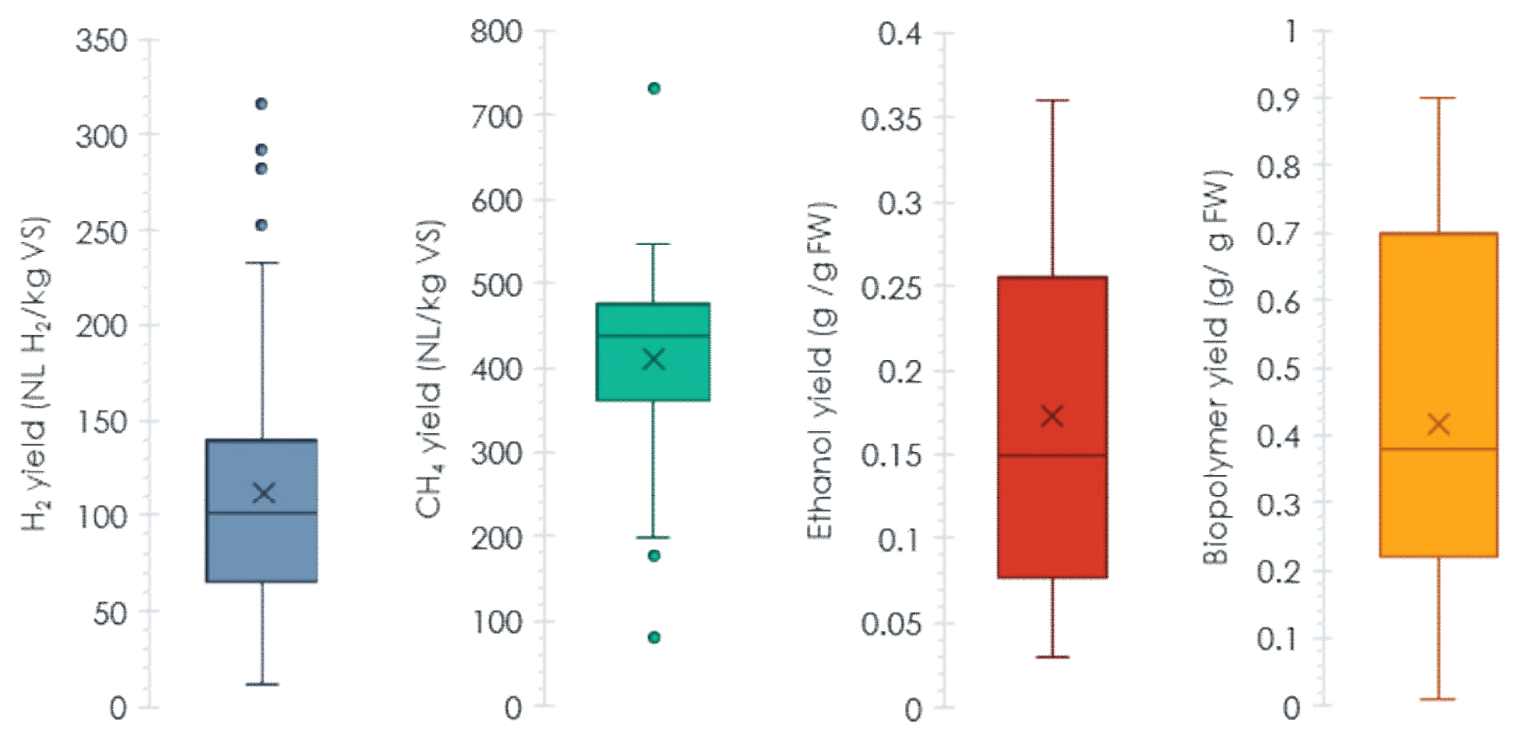

Figure 7. Yield ranges for $\mathrm{H}_{2}, \mathrm{CH}_{4}$, ethanol and biopolymers derived from literature references (Akhlaghi et al., 2019; Braguglia et al., 2018; Rodriguez-Perez et al., 2018; Srisowmeya et al., 2019; Tsang et al., 2019; Uçkun Kiran et al., 2014; Yadav et al., 2020 and references therein). The cross and the line within the box show the average and median value, respectively, the box denotes the range of $50 \%$ of data, whiskers range from the lower to the higher value within 1.5 interquartile ranges and circles stand for outliers. 


\section{Conclusions and recommendations}

The concept of organic waste biorefinery has the potential to open up a wide array of possibilities that may enable the waste management sector to improve the overall environmental, economic and social sustainability. Nevertheless, there are still numerous barriers and bottlenecks to overcome before the full implementation of biorefineries for waste management, which encompass environmental, technical, economic, social, logistic and legislative implications. From the technical standpoint, the waste biorefinery concept more and more requires that waste treatment is designed and operated industrially, with a high degree of technological development. To this aim, pretreatments, bioreactors and downstream separation processes require development to produce bioproducts with consistent physical-chemical characteristics at feasible costs.

Measures are needed from the point of view of policy making to foster sustainable bio-based solutions for waste management. In this regard, suitable strategies should be defined to support the development of the industrial sector in this field by identifying priority streamlines, introducing systematic and comprehensive regulatory measures, involving potential stakeholders, setting technical standards for bioproducts and, where necessary, defining new incentive schemes. The identification of specific targets for bioproducts production, in accordance with the circular economy principles set in the EU action plan (European Commission, 2015), could drive industries to focus on priority streamlines and technological advancement. This could be further supported by economic incentives such as carbon trading, excises on fossil-based products and more direct forms of subsidies. Inevitably, the economy will increasingly rely on sustainable sources of materials and fuels as non-renewable stocks are depleted and fossil sources will have to remain in the ground. Exploration of the diversity of products than can be derived from waste will therefore become increasingly important. 


\section{ACKNOWLEDGEMENTS}

This work was conducted in the framework of the activities of the "Waste Biorefinery" task group (for more information see https://www.tuhh.de/iue/iwwg/task-groups/waste-biorefinery.html), which is part of the International Waste Working Group (IWWG).

\section{REFERENCES}

Abels, C., Carstensen, F., Wessling, M., 2013. Membrane processes in biorefinery applications. J. Membr. Sci. 444, 285-317. https://doi.org/10.1016/j.memsci.2013.05.030

Akhlaghi, M., Boni, M.R., Polettini, A., Pomi, R., Rossi, A., De Gioannis, G., Muntoni, A., Spiga, D., 2019. Fermentative $\mathrm{H}_{2}$ production from food waste: Parametric analysis of factor effects.

Bioresour. Technol. 276, 349-360. https://doi.org/10.1016/j.biortech.2019.01.012

Albizzati, P.F., Tonini, D., Chammard, C.B., Astrup, T.F., 2019. Valorisation of surplus food in the French retail sector: Environmental and economic impacts. Waste Manage. 90, 141-151.

\section{https://doi.org/10.1016/j.wasman.2019.04.034}

Alibardi, L., Cossu, R., 2015. Composition variability of the organic fraction of municipal solid waste and effects on hydrogen and methane production potentials. Waste Manage. 36, 147-155. https://doi.org/10.1016/j.wasman.2014.11.019

Alibardi L., Cossu R., 2016. Effects of carbohydrate, protein and lipid content of organic waste on hydrogen production and fermentation products. Waste Manage. 47, 69-77. https://doi.org/10.1016/j.wasman.2015.07.049

Akhlaghi M., De Gioannis G., Muntoni A., Polettini A., Pomi R., Rossi A., Spiga D., 2016. Opportunities for the use of agroindustrial organic residues in biorefineries, Proc. SIDISA 2016, X 
International Symposium on Sanitary and Environmental Engineering, 19-23 June 2016, Rome (IT), ISBN: 978.88.496.391.1.7K.

Alvarenga, P., Mourinha, C., Farto, M., Santos, T., Palma, P., Sengo, J., Morais, M.-C., CunhaQueda, C., 2015. Sewage sludge, compost and other representative organic wastes as agricultural soil amendments: Benefits versus limiting factors. Waste Manage. 40, 44-52.

https://doi.org/10.1016/j.wasman.2015.01.027

Ao, T., Luo, Y., Chen, Y., Cao, Q., Liu, X., Li, D. 2020. Towards zero waste: A valorization route of washing separation and liquid hot water consecutive pretreatment to achieve solid vinasse based biorefinery. J. Clean. Prod. 248, 119253. https://doi.org/10.1016/j.jclepro.2019.119253

Arbige, M.V., Shetty, J.K., Chotani, G.K., 2019. Industrial Enzymology: The Next Chapter. Trends Biotechnol., 37, 12. https://doi.org/10.1016/j.tibtech.2019.09.010

Asquer, C., Cappai, G., Carucci, A., De Gioannis, G., Muntoni, A., Piredda, M., Spiga, D., 2019. Biomass ash characterisation for reuse as additive in composting process. Biomass Bioenerg. 123, 186-194. https://doi.org/10.1016/j.wasman.2017.08.009

Astrup, T. F., Tonini, D., Turconi, R., Boldrin, A., 2015. Life cycle assessment of thermal Wasteto-Energy technologies: Review and recommendations. Waste Manage. 37, 104-115. https://doi.org/10.1016/j.wasman.2014.06.011

Astrup, T.F., Pivnenko, K., Eriksen, M.K., Boldrin, A., 2018. Life Cycle Assessment of Waste Management: Are We Addressing the Key Challenges Ahead of Us? J. of Ind. Ecol. 22, 10001004. https://onlinelibrary.wiley.com/doi/abs/10.1111/jiec.12811 
Asunis, F., De Gioannis, G., Isipato, M., Muntoni, A., Polettini, A., Pomi, R., Rossi, A., Spiga, D., 2019. Control of fermentation duration and $\mathrm{pH}$ to orient biochemicals and biofuels production from cheese whey. Bioresour. Technol. 289,121722. https://doi.org/10.1016/j.biortech.2019.121722

Bajón Fernández Y., Green K., Schuler K., Soares A., Vale P., Alibardi L., Cartmell E. (2015). Biological carbon dioxide utilisation in food waste anaerobic digesters. Water Res. 87, 467-475. https://doi.org/10.1016/j.watres.2015.06.011

Batlle-Vilanova, P., Ganigué, R., Ramió-Pujol, S., Bañeras, L., Jiménez, G., Hidalgo, M., Balaguer, M.D., Colprim, J., Puig, S., 2017. Microbial electrosynthesis of butyrate from carbon dioxide: Production and extraction, Bioelectrochemistry 117, 57-64.

\section{https://doi.org/10.1016/j.bioelechem.2017.06.004}

Bavarella, S., Brookes, A., Moore, A., Vale, P., Di Profio, G., Curcio, E., Pidou, M., McAdam, E.J., 2019. Chemically reactive membrane crystallisation reactor for $\mathrm{CO}_{2}-\mathrm{NH}_{3}$ absorption and ammonium bicarbonate crystallisation: Kinetics of heterogeneous crystal growth. J. Membrane Sci. 599, 117682. https://doi.org/10.1016/j.memsci.2019.117682

Bisinella, V., Götze, R., Conradsen, K., Damgaard, A., Christensen, T.H., Astrup, T.F., 2017. Importance of waste composition for Life Cycle Assessment of waste management solutions. J. Clean. Prod. 164, 1180-1191. https://doi.org/10.1016/j.jclepro.2017.07.013

Boldrin, A., Neidel, T.L., Damgaard, A., Bhander, G.S., Møller, J., Christensen, T.H., 2011. Modelling of environmental impacts from biological treatment of organic municipal waste in EASEWASTE. Waste Manage. 31, 619-630. https://doi.org/10.1016/j.wasman.2010.10.025 
Braguglia, C.M., Gallipoli, A., Gianico, A., Pagliaccia, P., 2018. Anaerobic bioconversion of food waste into energy: A critical review. Bioresour. Technol. 248, 37-56.

https://doi.org/10.1016/j.biortech.2017.06.145

Budzianowski, W.M., Postawa, K., 2016. Total chain integration of sustainable biorefinery systems. Appl. Energ. 184, 1432-1446. https://doi.org/10.1016/j.apenergy.2016.06.050

Butkovskyi, A., Ni, G., Hernandez Leal, L., Rijnaarts, H.H.M., Zeeman, G., 2016. Mitigation of micropollutants for black water application in agriculture via composting of anaerobic sludge. J. Hazard. Mat. 303, 41-47. https://doi.org/10.1016/j.jhazmat.2015.10.016

Caldeira C., Vlysidisa A., Fiorea G., De Laurentiis V., Vignali G., Sala S., 2020. Sustainability of food waste biorefinery: A review on valorisation pathways, techno-economic constraints, and environmental assessment. Bioresour. Technol. 312, 123575. https://doi.org/10.1016/j.biortech.2020.123575

Carley, S., Browne, T.R., 2013. Innovative US energy policy: A review of states' policy experiences. Wires Energy Environ. 2, 488-506. https://doi.org/10.1002/wene.58

Cattle, S.R., Robinson, C., Whatmuff, M., 2020. The character and distribution of physical contaminants found in soil previously treated with mixed waste organic outputs and garden waste compost. Waste Manage. 101, 94-105. https://doi.org/10.1016/j.wasman.2019.09.043

Chandrasekhar, K., Lee, Y-J., Lee, D-W., 2015. Biohydrogen production: strategies to improve process efficiency through microbial routes. Int. J. Mol. Sci. 16, 8266-8293.

https://doi.org/10.3390/ijms16048266 
Chen, W.-S., Strik, D.P.B.T.B., Buisman, C.J.N., Kroeze, C., 2017. Production of Caproic Acid from Mixed Organic Waste: An Environmental Life Cycle Perspective. Environ. Sci. Technol. 51, 7159-7168. https://doi.org/10.1021/acs.est.6b06220

Cherubini, F., Jungmeier, G., Wellisch, M., Willke, T., Skiadas, I., Van Ree, R., de Jong, E. 2009. Toward a common classification approach for biorefinery systems. Biofuels, Bioprod. Bioref. DOI: 10.1002/bbb.172

Cherubini, F., 2010. The biorefinery concept: Using biomass instead of oil for producing energy and chemicals. Energy Convers. Manag. 51, 1412-1421.

https://doi.org/10.1016/j.enconman.2010.01.015

Clarke, W.P. 2018. The uptake of anaerobic digestion for the organic fraction of municipal solid waste - Push versus pull factors. Bioresour. Technol. 249, 1040-1043. https://doi.org/10.1016/j.biortech.2017.10.086

Coma M., Martinez-Hernandez E., Abeln F., Raikova S., Donnelly J., Arnot T. C., Allen M. J., Hong D. D., Chuck C. J., 2017. Organic waste as a sustainable feedstock for platform chemicals. Faraday Discuss. 202, 175-195. doi: 10.1039/c7fd00070g

Cossu, R., 2009. From triangles to cycles. Waste Manage. 29, 2915-2917. https://doi.org/10.1016/j.wasman.2009.09.002

Costa, G., Baciocchi, R., Polettini, A., Pomi, R., Hills, C.D., Carey, P.J., 2007. Current status and perspectives of accelerated carbonation processes on municipal waste combustion residues.

Environ. Monit. Assess. 135. https://doi.org/10.1007/s10661-007-9704-4 
Cristóbal J., Caldeira C., Corrado S., Sala, S., 2018. Techno-economic and profitability analysis of food waste biorefineries at European level. Bioresour. Technol. 259, 244-252. https://doi.org/10.1016/j.biortech.2018.03.016

De Gioannis, G., Muntoni, A., Polettini, A., Pomi, R., Spiga, D., 2017. Energy recovery from oneand two-stage anaerobic digestion of food waste. Waste Manage. 68, 595-602. https://doi.org/10.1016/j.wasman.2017.06.013

De Gioannis, G., Muntoni, A., Polettini, A., Pomi, R., 2013. A review of dark fermentative hydrogen production from biodegradable municipal waste fractions. Waste Manage. 33, 13451361. https://doi.org/10.1016/j.wasman.2013.02.019

den Boer, E., Łukaszewska, A., Kluczkiewicz, W., Lewandowska, D., King, K., Reijonen, T., Kuhmonen, T., Suhonen, A., Jääskeläinen, A., Heitto, A., Laatikainen, R., Hakalehto, E. 2016. Volatile fatty acids as an added value from biowaste. Waste Manage. 58, 62-69. https://doi.org/10.1016/j.wasman.2016.08.006

Diacono, M., Montemurro, F., 2010. Long-term effects of organic amendments on soil fertility. A review. Agron. Sustain. Dev. 30, 401-422. https://doi.org/10.1051/agro/2009040

Duan Y., Pandey A., Zhang Z., Awasthi M. K., Bhatia S. K., Taherzadeh M. J., 2020. Organic solid waste biorefinery: Sustainable strategy for emerging circular bioeconomy in China. Industrial Crops \& Products 153, 112568. https://doi.org/10.1016/j.indcrop.2020.112568

Dubois, J-L., 2012. Refinery of the future: feedstock, processes, products. In: Aresta, M., Dumeignil, F., Dibenedetto, A., 2012. Biorefinery. From Biomass to Chemicals and Fuels. Walter de Gruyter GmbH \& Co. KG, Berlin/Boston. ISBN 978-3-11-026023-6 
Duppeti, H., Chakraborty, S., Das, B.S., Mallick, N., Kotamreddy, J.N.R., 2017. Rapid assessment of algal biomass and pigment contents using diffuse reflectance spectroscopy and chemometrics. Algal Res. 27, 274-285. https://doi.org/10.1016/j.algal.2017.09.016

Eriksson, O., Carlsson Reich, M., Frostell, B., Björklund, A., Assefa, G., Sundqvist, J.-O., Granath, J., Baky, A., Thyselius, L., 2005. Municipal solid waste management from a systems perspective. J. Clean. Prod 13, 241-252. https://doi.org/10.1016/j.jclepro.2004.02.018

Escamilla-Alvarado, C., Pérez-Pimienta, J.A., Ponce-Noyola, T., Poggi-Varaldo, H.M., 2017. An overview of the enzyme potential in bioenergy-producing biorefineries. J. Chem. Technol. Biot. 92, 906-924. https://doi.org/10.1002/jctb.5088

European Biogas Association (EBA), 2018. Statistical Report of the European Biogas Association 2018. Brussels, Belgium.

European Commission, 2015. Closing the loop - An EU action plan for the Circular Economy. COM/2015/0614 https://doi.org/10.1017/CBO9781107415324.00

European Commission, 2011. Communication from the Commission to the European Parliament, the Council, the European Economic and Social Committee and the Committee of the Regions. Energy Roadmap 2050, COM/2011/0885 final.

Eurostat, 2016. Generation of waste by waste category, https://ec.europa.eu/eurostat/databrowser/view/ten00108/default/table?lang=en, accessed March 2020. 
Fava F., Totaro G., Diels L., Reis M., Duarte J., Beserra Carioca O., Poggi-Varaldo H.M., Sommer Ferreira B., 2015. Biowaste biorefinery in Europe: opportunities and research \& development needs. New Biotechnology 32, 100-108. https://doi.org/10.1016/j.nbt.2013.11.003.

Fiormarket, 2019. https://www.fiormarkets.com/report/global-organic-chemicals-market-bychemical-type-product-375927.html

Galanopoulos C., Giuliano A., Barletta D., Zondervan E., (2020) AN integrated methodology for the economic and environmental assessment of a biorefinery supply chain, Chemical Engineering Research and Design. http://doi.org/https://doi.org/10.1016/j.cherd.2020.05.016

Girotto, F., Cossu, R., 2019. Role of animals in waste management with a focus on invertebrates' biorefinery: An overview. Environ. Dev. 32,100454. https://doi.org/10.1016/j.envdev.2019.08.001

Girotto, F., Alibardi L., Cossu R., 2015. Food waste generation and industrial uses: A review. Waste Manage. 45, 32-41. https://doi.org/10.1016/j.wasman.2015.06.008

Go L. C., Fortela D. L. B., Revellame E., Zappi M., Chirdon W., Holmes W., Hernandez R., 2019. Biobased chemical and energy recovered from waste microbial matrices. Bioresour. Technol. 26, 65-71. https://doi.org/10.1016/j.coche.2019.08.005

Hennebert, P., 2018. Proposal of concentration limits for determining the hazard property HP 14 for waste using ecotoxicological tests. Waste Manage. 74, 74-85.

https://doi.org/10.1016/j.wasman.2017.11.048

Huang, H.-J., Ramaswamy, S., Tschirner, U.W., Ramarao, B.V., 2008. A review of separation technologies in current and future biorefineries. Sep. Pur. Technol. 62, 1-21

https://doi.org/10.1016/j.seppur.2007.12.011 
IEA Bioenergy - Task 42 Biorefinery, 2012. Bio-based Chemicals - Value Added Products from Biorefineries._30

IEA Bioenergy Task42, 2020. Bio-Based Chemicals: a 2020 Update.

ISO, 2006. Environmental Management - Life Cycle Assessment - Requirements and Guidelines, first ed., ISO; Geneva, Switzerland.

Jones, R.J., Massanet-Nicolau, J., Mulder, M.J.J., Premier, G., Dinsdale, R., Guwy, A., 2017. Increased biohydrogen yields, volatile fatty acid production and substrate utilisation rates via the electrodialysis of a continually fed sucrose fermenter. Bioresour. Technol. 229, 46-52. https://doi.org/10.1016/j.biortech.2017.01.015

Khetkorn, W., Rastogi, R.P., Incharoensakdi, A., Lindblad, P., Madamwar, D., Pandey, A., Larroche, C., 2017. Microalgal hydrogen production - A review. Bioresour. Technol. 243, 1194 1206. https://doi.org/10.1016/j.biortech.2017.07.085

Kapoor, R., Ghosh, P., Kumar, M., Vijay, V.K., 2019. Evaluation of biogas upgrading technologies and future perspectives: a review. Environ. Sci. Pollut. R. 26, 11631-11661. https://doi.org/10.1007/s11356-019-04767-1

Kougias, P.G., Angelidaki, I. 2018. Biogas and its opportunities - A review. Front. Env. Sci. Eng. 12. https://doi.org/10.1007/s11783-018-1037-8

Kuchta, K., 2016. Prospects and potentials of waste biorefineries. Lecture at "SIDISA 2016 - X International Symposium on Sanitary and Environmental Engineering, 19-23 June 2016, Rome, Italy. 
Lamb, K.E., Dolan, M.D., Kennedy, D.F., 2019. Ammonia for hydrogen storage; A review of catalytic ammonia decomposition and hydrogen separation and purification. Int. J. Hydrogen Energ. 44, 3580-3593. https://doi.org/10.1016/j.ijhydene.2018.12.024

Lin, C-Y., Nguyen, T. M-L., Chu, C-Y., Leu, H-J., Lay, C-H., 2018. Fermentative biohydrogen production and its byproducts: A mini review of current technology developments. Renew. Sust. Energ. Rev. 82, 4215-4220. https://doi.org/10.1016/j.rser.2017.11.001

Lombardi, L., Francini 2020. Techno-economic and environmental assessment of the main biogas upgrading technologies. Submitted to Renewable Energy.

Lodato, C., Tonini, D., Damgaard, A., Astrup, T. F., 2020. A process-oriented life-cycle assessment (LCA) model for environmental and resource-related technologies (EASETECH). Int. J. Life Cycle Ass. 25, 73-88. https://doi.org/10.1007/s11367-019-01665-Z

Lohrasbi M., Pourbafrani M., Niklasson C., Taherzadeh M.J., 2010. Process design and economic analysis of a citrus waste biorefinery with biofuels and limonene as products. Bioresour. Technol. 101, 7382-7388. https://doi.org/10.1016/j.biortech.2010.04.078.

Lu, J., Zahedi, A., Yang, C., Wang, M., Peng, B., 2013. Building the hydrogen economy in China: Drivers, resources and technologies. Renew. Sust. Energ. Rev. 23, 543-556.

\section{https://doi.org/10.1016/j.rser.2013.02.042}

Ma, Y., Liu, Y., 2019. Turning food waste to energy and resources towards a great environmental and economic sustainability: An innovative integrated biological approach. Biotechnol. Adv. 37, 107414. https://doi.org/10.1016/j.biotechadv.2019.06.013 
Ma, H., Guo, Y., Qin, Y., Li, Y.-Y., 2018. Nutrient recovery technologies integrated with energy recovery by waste biomass anaerobic digestion. Bioresour. Technol. 269, 520-531. https://doi.org/10.1016/j.biortech.2018.08.114

Maina, S., Kachrimanidou, V., Koutinas, A., 2017. A roadmap towards a circular and sustainable bioeconomy through waste valorization. Curr. Opin. Green Sustain. Chem. 8, 18-23.

Matharu, A.S., de Melo, E.M., Houghton, J.A., 2016. Opportunity for high value-added chemicals from food supply chain wastes. Bioresour. Technol. 215, 123-130.

\section{https://doi.org/10.1016/j.biortech.2016.03.039}

Morello, L., Raga, R., Sgarbossa, P., Rosson, E., Cossu, R., 2018. Storage potential and residual emissions from fresh and stabilized waste samples from a landfill simulation experiment. Waste Manage. 75, 372-383. https://doi.org/10.1016/j.wasman.2018.01.026

Moretti, M., Van Dael, M., Malina, R., Van Passel, S., 2017. Environmental assessment of waste feedstock mono-dimensional and bio-refinery systems: Combining manure co-digestion and municipal waste anaerobic digestion. J. Clean. Prod. 171, 954-961.

https://doi.org/10.1016/j.jclepro.2017.10.097

Moretto, G., Valentino, F., Pavan, P., Majone, M., Bolzonella, D., 2019. Optimization of urban waste fermentation for volatile fatty acids production. Waste Manage. Volume 92, 1 June 2019, Pages 21-29. https://doi.org/10.1016/j.wasman.2019.05.010

Moscoviz, R., Trably, E., Bernet, N., Carrère, H., 2018. The environmental biorefinery: State-ofthe-art on the production of hydrogen and value-added biomolecules in mixed-culture fermentation. Green Chem. 20(14), 3159-3179. https://doi.org/10.1039/C8GC00572A 
Muntoni, A., 2019. Waste biorefineries: opportunities and perspectives. Detritus 05, 1-2.

Naik, S.N., Goud, V. V., Rout, P.K., Dalai, A.K., 2010. Production of first and second generation biofuels: A comprehensive review. Renew. Sustain. Energy Rev. 14, 578-597. https://doi.org/10.1016/j.rser.2009.10.003

Nizami, A.S., Rehan, M., Waqas, M., Naqvi, M., Ouda, O.K.M., Shahzad, K., Miandad, R., Khan, M.Z., Syamsiro, M., Ismail, I.M.I., Pant, D., 2017. Waste biorefineries: Enabling circular economies in developing countries. Bioresour. Technol., 241, 1101-1117.

\section{https://doi.org/10.1016/j.biortech.2017.05.097}

Olsson, O., Bruce, L., Roos, A., Hektor, B., Guisson, R., Lamers, P., Hartley, D., Ponitka, J., Hildedrandt, J., Thrän, D. 2016. Cascading of Woody Biomass: definitions, policies and effects on international trade. IEA Bioenergy Task 40. April 2016.

Outram, V., Zhang, Y., 2018. Solvent-free membrane extraction of volatile fatty acids from acidogenic fermentation. Bioresour. Technol. 270, 400-408.

https://doi.org/10.1016/j.biortech.2018.09.057.

Papież, M., Śmiech, S., Frodyma, K., 2018. Determinants of renewable energy development in the EU countries. A 20-year perspective. Renew. Sust. Energ. Rev. 91, 918-934.

\section{https://doi.org/10.1016/j.rser.2018.04.075}

Poggi-Varaldo M., Héctor \& Muñoz-Páez, Karla \& Escamilla-Alvarado, Carlos \& N RobledoNarváez, Paula \& Teresa Ponce-Noyola, M \& Calva-Calva, Graciano \& Ríos-Leal, Elvira \& Galindez-Mayer, Juvencio \& Est Váz, Carlos \& Ortega-Clemente, Alfredo \& F RinderknechtSeijas, Noemi. (2014). Biohydrogen, biomethane and bioelectricity as crucial components of 
biorefinery of organic wastes: A review. Waste Manage. Res. 32.

https://doi.org/10.1177\%2F0734242X14529178

Pyrgakis K.A. and Kokossis A.C., 2019. A total site synthesis approach for the selection, integration and planning of multiple-feedstock biorefineries. Comput. Chem. Eng. 122, 326-355. https://doi.org/10.1016/j.compchemeng.2018.09.003

Rebecchi, S., Pinelli, D., Bertin, L., Zama, F., Fava, F., Frascari, D., 2016. Volatile fatty acids recovery from the effluent of an acidogenic digestion process fed with grape pomace by adsorption on ion exchange resins. Chem. Eng. J. 306, 629-639. https://doi.org/10.1016/j.cej.2016.07.101.

Reyhanitash, E., Zaalberg, B., Kersten, S.R.A., Schuur, B., 2016. Extraction of volatile fatty acids 832 from fermented wastewater. Sep. Purif. Technol. 161, 61-68. https://doi.org/10.1016/j.seppur.2016.01.037.

Rodriguez-Perez, S., Serrano, A., Pantión, A.A., Alonso-Fariñas, B., 2018. Challenges of scaling-up PHA production from waste streams. A review. J. Environ. Manage. 205, 215-230. optimization to evaluate multiple feedstocks for a biorefinery. Applied Energy 254, 113660.

839 https://doi.org/10.1016/j.apenergy.2019.113660

840 Sadhukhan, J., Ng, K.S., Martinez-Hernandez, E., 2016. Novel integrated mechanical biological 841 chemical treatment (MBCT) systems for the production of levulinic acid from fraction of municipal 842 solid waste: a comprehensive techno-economic analysis. Bioresour. Technol. 215, 131-143. 
Sadhukhan, J., Martinez-Hernandez, E., 2017. Material flow and sustainability analyses of biorefining of municipal solid waste. Bioresour. Technol., 243, 135-146.

https://doi.org/10.1016/j.biortech.2017.06.078

Sadhukhan, J., Martinez-Hernandez, E., Murphy, R.J., Ng, D.K.S., Hassim, M.H., Siew Ng, K., Yoke Kin, W., Jaye, I.F.M., Leung Pah Hang, M.Y., Andiappan, V., 2018. Role of bioenergy, biorefinery and bioeconomy in sustainable development: Strategic pathways for Malaysia. Renew. Sust. Energ. Rev. 81, 1966-1987. https://doi.org/10.1016/j.rser.2017.06.007

Sanna, A., Uibu, M., Caramanna, G., Kuusik, R., Maroto-Valer, M.M., 2014. A review of mineral carbonation technologies to sequester $\mathrm{CO}_{2}$. Chem. Soc. Rev. 43, 8049-8080. https://doi.org/10.1039/C4CS00035H

Sarc, R., Curtis, A., Kandlbauer, L., Khodier, K., Lorber, K.E., Pomberger, R., 2019. Digitalisation and intelligent robotics in value chain of circular economy oriented waste management - A review. Waste Manage. 95, 476-492. https://doi.org/10.1016/j.wasman.2019.06.035

Satari B. and Karimi K., 2018. Citrus processing wastes: Environmental impacts, recent advances, and future perspectives in total valorization. Resour. Conserv. Recy. 129, 153-167. http://dx.doi.org/10.1016/j.resconrec.2017.10.032.

Schieb P-A., Lescieux-Katir, H., Thénot, M., Clément-Larosière, B., 2015. Biorefinery 2030. Future Prospects for the Bioeconomy. Springer-Verlag GmbH Berlin Heidelberg DOI 10.1007/978$3-662-47374-0$

Shahzad, K., Narodoslawsky, M., Sagir, M., Ali, N., Ali, S., Rashid, M.I., Ismail, I.M.I., Koller, M. 2017. Techno-economic feasibility of waste biorefinery: Using slaughtering waste streams as 
starting material for biopolyester production. Waste Manage. 67, 73-85.

https://doi.org/10.1016/j.wasman.2017.05.047

Sharma, B., Vaish, B., Monika, Singh, U.K., Singh, P., Singh, R.P., 2019. Recycling of Organic Wastes in Agriculture: An Environmental Perspective. Int. J. Environ. Res. 13, 409-429 https://doi.org/10.1007/s41742-019-00175-y

Srisowmeya, G., Chakravarthy, M., Nandhini Devi, G., 2019. Critical considerations in two-stage anaerobic digestion of food waste - A review. Renew. Sustain. Energ. Rev. 109587. https://doi.org/10.1016/j.rser.2019.109587

Strong, P.J., Xie, S., Clarke, W.P., 2015. Methane as a resource: Can the methanotrophs add value? Environ. Sci. Technol. 49, 4001-4018 https://doi.org/10.1021/es504242n

Strong, P.J., Kalyuzhnaya, M., Silverman, J., Clarke, W.P., 2016. A methanotroph-based biorefinery: Potential scenarios for generating multiple products from a single fermentation. Bioresour. Technol. 215, 314-323. https://doi.org/10.1016/j.biortech.2016.04.099

Tinikul, R., Chenprakhon, P., Maenpuen, S., Chaiyen, P. 2018. Biotransformation of Plant-Derived Phenolic Acids. Biotechnol. J. 13,1700632. https://doi.org/10.1002/biot.201700632

880 Tonini, D., Astrup, T., 2012. Life-cycle assessment of a waste refinery process for enzymatic 881 treatment of municipal solid waste. Waste Manage. 32, 165-176.

882 https://doi.org/10.1016/j.wasman.2011.07.027

Tonini, D., Martinez-Sanchez, V., \& Astrup, T. F., 2013. Material resources, energy, and nutrient recovery from waste: are waste refineries the solution for the future? Environ. Sci. Technol. 47, 8962-8969. https://doi.org/10.1021/es400998y 
Tonini, D., Hamelin, L., Alvarado-Morales, M., \& Astrup, T. F., 2016. GHG emission factors for bioelectricity, biomethane, and bioethanol quantified for 24 biomass substrates with consequential life-cycle assessment. Bioresour. Technol., 208, 123-133.

https://doi.org/10.1016/j.biortech.2016.02.052

Tsang, Y.F., Kumar, V., Samadar, P., Yang, Y., Lee, J., Ok, Y.S., Song, H., Kim, K.-H., Kwon, E.E., Jeon, Y.J., 2019. Production of bioplastic through food waste valorization. Environ. Int. 127, 625-644. https://doi.org/10.1016/j.envint.2019.03.076

Ubando, A.T., Felix, C.B., Chen, W-H. 2020. Biorefineries in circular bioeconomy: A comprehensive review. Bioresource Technology 299, 122585

https://doi.org/10.1016/j.biortech.2019.122585

Uçkun Kiran, E., Trzcinski, A.P., Ng, W.J., Liu, Y., 2014. Bioconversion of food waste to energy: A review. Fuel 134, 389-399. https://doi.org/10.1016/j.fuel.2014.05.074

Valentino, F., Morgan-Sagastume, F., Campanari, S., Villano, M., Werker, A., Majone, M., 2017. Carbon recovery from wastewater through bioconversion into biodegradable polymers, $\mathrm{N}$.

Biotechnol., 37, 9-23. https://doi.org/10.1016/j.nbt.2016.05.007

Venkata Mohan, S., Rohit, M.V., Chiranjeevi, P., Chandra, R., Navaneeth, B., 2015. Heterotrophic microalgae cultivation to synergize biodiesel production with waste remediation: Progress and perspectives. Bioresour. Technol. 184, 169-178. https://doi.org/10.1016/j.biortech.2014.10.056

Venkata Mohan, S., Nikhil, G.N., Chiranjeevi, P., Nagendranatha Reddy, C., Rohit, M.V., Kumar, A.N., Sarkar, O., 2016. Waste biorefinery models towards sustainable circular bioeconomy: Critical review and future perspectives. Bioresour. Technol. 215, 2-12.

https://doi.org/10.1016/j.biortech.2016.03.130 
Vrancken, C., Longhurst, P.J., Wagland, S.T. 2017. Critical review of real-time methods for solid waste characterisation: Informing material recovery and fuel production. Waste Manage. 61, 40-57. https://doi.org/10.1016/j.wasman.2017.01.019

Walmsley, T.G., Ong, B.H.Y., Klemeš, J.J., Tan, R.R., Varbanov, P.S., 2019. Circular Integration of processes, industries, and economies. Renew. Sust. Energ. Rev. 107, 507-515. https://doi.org/10.1016/j.rser.2019.03.039

Xiong, B., Richard, T.L., Kumar, K., 2015. Integrated acidogenic digestion and carboxylic acid separation by nanofiltration membranes for the lignocellulosic carboxylate platform. J. Membr. Sci. 489, 275-283. https://doi.org/10.1016/j.memsci.2015.04.022

Yadav, B., Pandey, A., Kumar, L.R., Tyagi, R.D., 2020. Bioconversion of waste (water)/residues to bioplastics - A circular bioeconomy approach. Bioresour. Technol. 298, 122584. https://doi.org/10.1016/j.biortech.2019.122584

Zhang, Q., Wang, Y., Zhang, Z., Lee, D-J., Zhou, X., Jing, Y., Ge, X., Jiang, D., Hua, J., He, C., 2017. Photo-fermentative hydrogen production from crop residue: A mini review. Bioresour. Technol. 229, 222-230. https://doi.org/10.1016/j.biortech.2017.01.008 